\title{
Review Article \\ The Bioethanol Industry in Sub-Saharan Africa: History, Challenges, and Prospects
}

\author{
Evanie Devi Deenanath, ${ }^{1}$ Sunny Iyuke, ${ }^{1}$ and Karl Rumbold ${ }^{2}$ \\ ${ }^{1}$ School of Chemical and Metallurgical Engineering, University of the Witwatersrand, 1 Jan Smuts Avenue, Braamfontein, \\ Johannesburg 2000, South Africa \\ ${ }^{2}$ School of Molecular and Cell Biology, University of the Witwatersrand, 1 Jan Smuts Avenue, Braamfontein, \\ Johannesburg 2000, South Africa \\ Correspondence should be addressed to Evanie Devi Deenanath, edeenanath@yahoo.com
}

Received 17 October 2011; Revised 22 November 2011; Accepted 8 January 2012

Academic Editor: Guihua H. Bai

Copyright (C) 2012 Evanie Devi Deenanath et al. This is an open access article distributed under the Creative Commons Attribution License, which permits unrestricted use, distribution, and reproduction in any medium, provided the original work is properly cited.

\begin{abstract}
Recently, interest in using bioethanol as an alternative to petroleum fuel has been escalating due to decrease in the availability of crude oil. The application of bioethanol in the motor-fuel industry can contribute to reduction in the use of fossil fuels and in turn to decreased carbon emissions and stress of the rapid decline in crude oil availability. Bioethanol production methods are numerous and vary with the types of feedstock used. Feedstocks can be cereal grains (first generation feedstock), lignocellulose (second generation feedstock), or algae (third generation feedstock) feedstocks. To date, USA and Brazil are the leading contributors to global bioethanol production. In sub-Saharan Africa, bioethanol production is stagnant. During the 1980s, bioethanol production has been successful in several countries including Zimbabwe, Malawi, and Kenya. However, because of numerous challenges such as food security, land availability, and government policies, achieving sustainability was a major hurdle. This paper examines the history and challenges of bioethanol production in sub-Saharan Africa (SSA) and demonstrates the bioethanol production potential in SSA with a focus on using bitter sorghum and cashew apple juice as unconventional feedstocks for bioethanol production.
\end{abstract}

\section{Introduction}

With progressive global dilemmas such as increased greenhouse gas emissions, depleted crude oil supply, and rising fuel prices $[1,2]$, the need for biofuels has sparked an exponential interest to ease the reduction in nonrenewable energy resources and to further prevent global warming from carbon emission. The major contributor to the level of environmental pollution is motor vehicles that emit approximately $70 \%$ of carbon monoxide and 19\% of carbon dioxide globally [3]. Hence, transportation industries can utilize biofuels as a fossil fuel substitute [4]. Biofuels can be divided into five categories: bioethanol, biodiesel, biogas, biomethanol, and biohydrogen [5]. The different types of biofuels are sourced from starch-rich crops for bioethanol, vegetable oils for biodiesel, organic waste for biogas, cellulose for biomethanol, and steam reforming for biohydrogen [4]. Bioethanol and biodiesel are the most common types of biofuels. The use of bioethanol and biodiesel as transport fuels is very attractive due to reduction of combustion emissions, accessibility from renewable resources, and biodegradability [57]. Over the past decade the production of bioethanol and biodiesel has been extensively investigated worldwide and the production methods proved successful in USA and Brazil $[3,6,8,9]$. However, in Sub-Saharan Africa (SSA) large-scale industrial production and commercialization are stagnant. Thus, this paper is to provide a review on potential of bioethanol as a type of biofuel in SSA.

\section{Overview of Bioethanol}

The term bioethanol is defined as an ethyl alcohol or ethanol $\left(\mathrm{CH}_{3}-\mathrm{CH}_{2}-\mathrm{OH}\right)$ produced via biological processes that convert biomass into bioethanol through biochemical processes 
such as hydrolysis and microbiological fermentation, rather than ethylene hydration and gasification $[6,7,10]$. Biomass includes cereal grains, lignocelluloses, or algae $[6,7]$.

Bioethanol as a transport fuel (Table 1) offer numerous advantages over traditional fuel such as (i) premature ignition and prevention of cylinder knocking due to the higher octane number and higher heat of vaporization compared to traditional fuel; (ii) reduction in hydrocarbon and carbon monoxide exhaust emission based on the higher oxygen content of bioethanol; (iii) in an internal combustion engine the lower energy content of bioethanol allows for direct addition as a bioethanol-fuel blend as the compression ratio is higher and burn time is shorter; (iv) the blending or mixing of bioethanol with traditional fuel is compatible with current engine designs; and (v) bioethanol is chemically miscible in petrol $[6,10-13]$. However, there are disadvantages associated with bioethanol. For example, combustion of bioethanol when blended with petrol releases formaldehyde and acetaldehyde, which are toxic to human [10]. Another major disadvantage is the fuel versus food security issue. The use of agricultural products such as cereal grains will limit food and feed reserves in developing countries, leading to possible food crisis $[5,10,14]$.

Globally, the production of biofuels has increased from 4.8 billion gallons to 16.0 billion gallons between the years 2000 to 2007 [12]. Currently, the USA and Brazil are the dominating bioethanol producers, contributing approximately $75-80 \%$ of the world's bioethanol production [10, 12 ]. In the USA, corn grain is the common feedstock used and accounts for $90 \%$ of bioethanol production [6]. With 187 commercial bioethanol plants, the USA aims to produce 57 billion liters by the year 2012 and 136 billion liters by the year 2022 from the use of additional feedstocks such as maize and sugar cane [10]. In Brazil, sugar cane is the preferred feedstock [6] and is estimated to produce 37 billion liters by 2013 [10]. During 2011, the European Union (EU) bioethanol production has increased to approximately 2.0 billion gallons. The EU is dependent on wheat and sugar beet as the sole bioethanol feedstocks $[6,10]$.

A variety of feedstocks can be used for the production of bioethanol. They can be classified into first, second, and third generation feedstocks, depending on the sources of carbohydrate materials. First-generation feedstocks are starchy materials including cereal grains and sucrose-rich materials such as sugar cane $[6,10]$. Second-generation feedstocks are predominantly lignocellulosic materials such as wheat straw, switchgrass and corncobs, to name a few $[6,10]$. Third generation feedstocks are macroalgae biomass such as seaweed [15]. An overview of the bioethanol production methods is outlined in Figures 1, 2, 3. In general, bioethanol is derived from feedstocks by hydrolysis, followed by microbial fermentation (Figures 1-3). Hydrolysis into fermentable sugars can be acidic or enzymatic based on the type of feedstock used (Figures 1-3) [6, 13, 16]. For fermentation, Saccharomyces $(S$.) cerevisiae is the preferred microorganism (MO) for its ability to easily convert sugars and its potential to proliferate anaerobically [13]. An additional aspect of the production process is pretreatment. Pretreatment methods such as physical, physico-chemical, chemical, and biological methods are required to change the complex structure by removing the lignin and hemicelluloses and reducing cellulose. This is necessary to produce accessible enzyme substrate for hydrolysis $[6,13,17]$. These methods used for pretreatment are vast and have been extensively documented elsewhere $[6,13,16,17]$.

\section{History and Challenges of Bioethanol Production in Sub-Saharan Africa}

3.1. History of Bioethanol Production. Bioethanol production in SSA can be dated back to 1980 with the most successful plants developed in Zimbabwe, Malawi, and Kenya [3, 5, 14, 18-20]. The Zimbabwean Triangle Ethanol Plant began production in 1980, producing approximately 120,000 liters of bioethanol daily and 40 million liters annually for 12 years $[3,14,20]$. Sugar cane molasses was the main feedstock used, with the sugar cane being cultivated locally $[3,20]$. The Triangle Ethanol Plant was the first in SSA to blend 1215\% (v/v) of bioethanol with petrol [5]. However, in 1992 drought conditions caused a severe reduction in sugar cane production, which resulted in shutting down the plant due to the lack of government support in reviving the land $[14,18]$.

In Malawi, bioethanol production began in 1982 at the Dwangwa Estate Plant that produced 15 to 20 million liters annually from sugar cane molasses $[5,14,19]$. Currently, this plant is still in production. A second plant, Nchalo Plant, was opened in 2004 with productivity of approximately 12 million liters annually. Blending of $10 \%(\mathrm{v} / \mathrm{v})$ bioethanol with petrol is practiced at these plants $[5,14]$. The sustainability of bioethanol production in Malawi is contributed by government policies including (i) "reducing imported fossil fuels" [5], (ii) increasing production of feedstocks from smallholder farmers, (iii) consistent water supply from Lake Malawi, and (iv) allocation of $\$ 8$ million for biofuel production $[5,14,19]$.

In Kenya, the Muhoroni Plant produced 45,000 liters of bioethanol daily from sugar cane molasses. Like in Malawi, $10 \%(\mathrm{v} / \mathrm{v})$ of ethanol was blended with petrol $[14,20]$. However, the plant was closed in 1993 because of financial crisis and lack of support from government and oil companies $[14,20]$.

\subsection{Challenges of Bioethanol Production}

3.2.1. Feedstocks for Bioethanol Production. The availability of crops as feedstocks for bioethanol production exacerbates the debate of fuel versus food. In SSA, crops are major sources of food for the human population. For example, 95\% of maize cultivated in Zambia is consumed as the staple food [14]. If maize is to be used as a fuel crop as in the USA this will in turn cause a significant increase in food prices. In Mauritius, sugar cane and the bagasse are utilized for the generation of electricity and heat. Hence, in addition to the food supply being affected, if sugar cane is utilized for bioethanol then the electricity supply will also be threatened [20]. Furthermore, the demand for food in SSA for basic domestic needs is increasing, and in the year $200033 \%$ of 
TABLE 1: Properties of bioethanol as a transport fuel.

\begin{tabular}{lccc}
\hline Desired fuel property & Traditional fuel property & Bioethanol-fuel property & Reference \\
\hline High octane number & 88 & 107 & {$[6,10]$} \\
High oxygen content & $2.7 \%(\mathrm{w} / \mathrm{w})$ & $35 \%(\mathrm{w} / \mathrm{w})$ & {$[6,53]$} \\
Low energy content & $31.3 \mathrm{MJ} / \mathrm{dm}^{3}$ & $21.2 \mathrm{MJ} / \mathrm{dm}^{3}$ & {$[12]$} \\
High Latent heat of vaporization & $0.30 \mathrm{MJ} / \mathrm{kg}$ & $0.91 \mathrm{MJ} / \mathrm{kg}$ & {$[6,54]$} \\
Low heating value & $43.0 \mathrm{MJ} / \mathrm{kg}$ & $26.7 \mathrm{MJ} / \mathrm{kg}$ & {$[6,54]$} \\
\hline
\end{tabular}

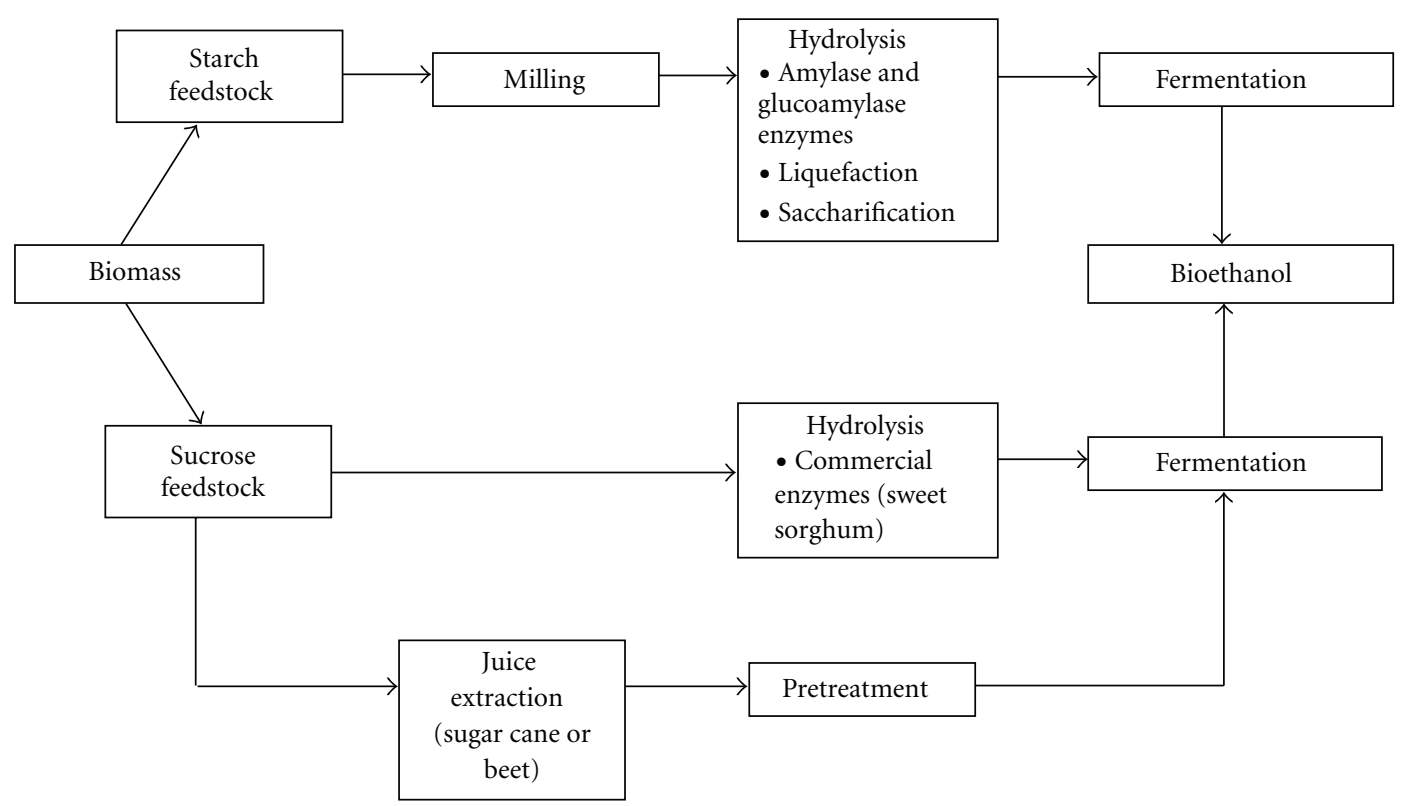

FIGURE 1: A diagram of bioethanol production from starch and sucrose feedstocks (modified from $[6,10]$ ).

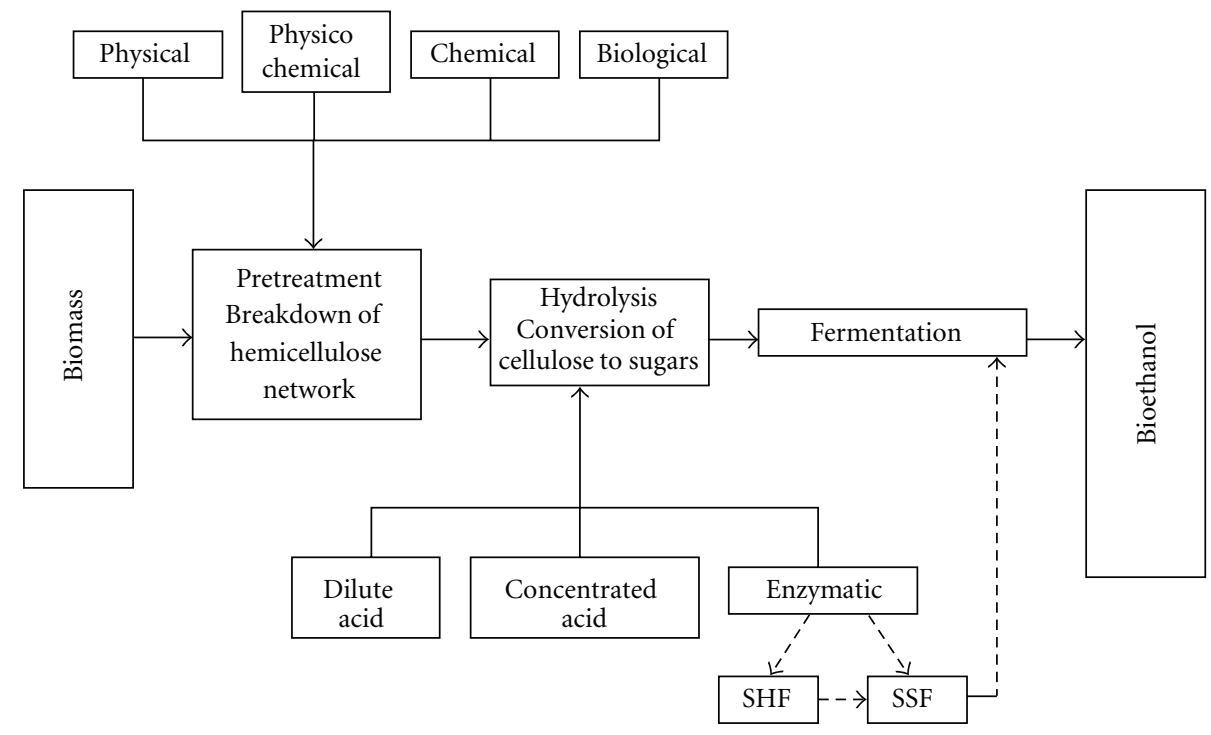

FIGURE 2: A diagram of bioethanol production from lignocellulosic feedstocks (modified from [10]). 


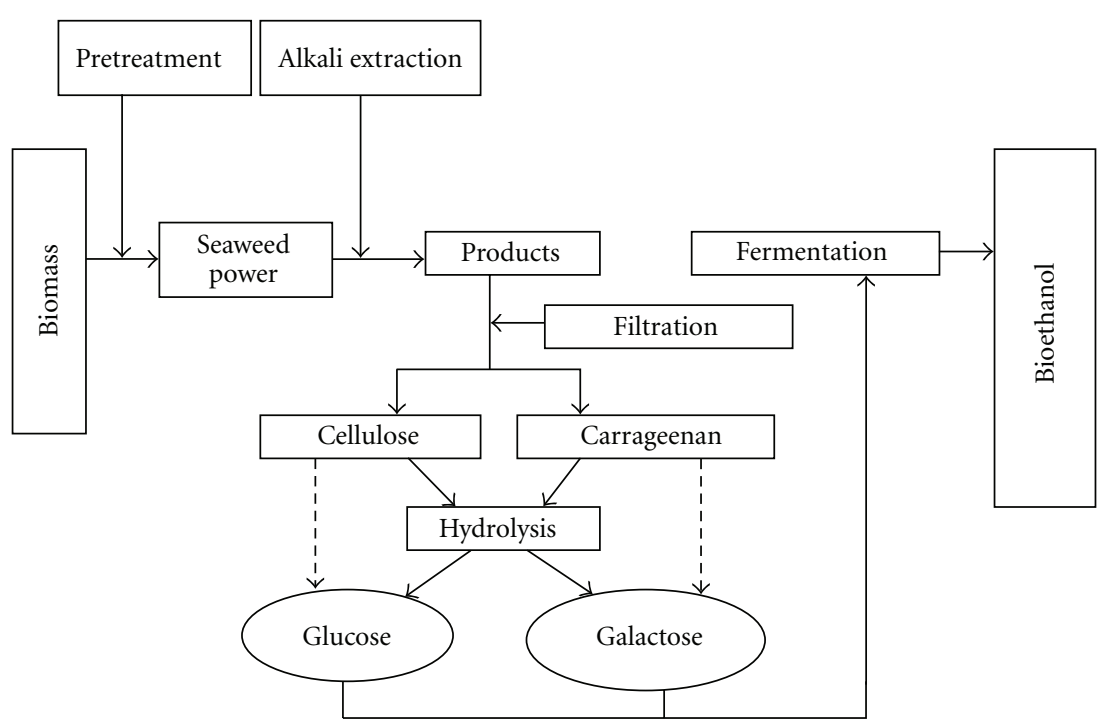

FIgURE 3: A diagram of bioethanol production from seaweed (modified from [15]).

crops had to be imported to meet human food consumption without using crops as a source of biofuel [5].

3.2.2. Land Availability and Development. Similar to the fuel versus food debate, the dilemma of land availability is whether or not to use the majority of the land for food crop or bioethanol crop cultivation. Agricultural land in Tanzania, for example, is owned by smallholder farmers in which farming is their way of life [5]. If their land is converted for bioethanol crop production it raises the questions that whether these farmers can benefit economically from bioethanol crops and whether they will have enough food to feed the growing population.

In Burkina Faso, limited land for crops is usually for women for household needs and for medicinal uses [5, 14]. Large-scale bioethanol production requires large area of land for biofuel crop production. This may result in the use of these limited crop land, and, therefore, reduction in the amount of land available to African women for maintaining their basic living $[5,14]$.

In Cameroon, $75 \%$ of agricultural work is carried out by women; however only $10 \%$ of the land is owned by these women [5]. The use of this land for bioethanol crops will seriously disadvantage the women owners, because these owners cannot receive bank credit for bioethanol crop production [5]. Furthermore, expansion of agricultural land for biofuel crop production will result in severe deforestation, loss of biodiversity, and erosion of the organic soil matter $[5,14,21]$.

3.2.3. Government Policies. SSA consists of largely poor rural areas with poor production markets, severe poverty, high child mortality rates, high HIV infection rates, women marginalization, and extreme dependence on agriculture for food and livelihood [18, 21]. The vulnerability of these situations overshadows government policies and full support towards sustainable bioethanol development. To date, bioethanol policies have been proposed in sub-Saharan regions such as Mozambique, Nigeria, Uganda, South Africa, Malawi, and Ghana [5, 19]. The Mozambican government has adopted policies of blending 5-10\% (v/v) of bioethanol with petrol, whereas in South Africa the government suggests that 400 million liters of biofuels will be produced by the year 2013 [19]. However, these policies resemble vague phrases and lack of financial obligations, coordinated research, and educational training to acquire necessary skills $[5,19]$. Furthermore, these policies do not allow for international trade, and investments; thus bioethanol production in SSA cannot be recognized on the global scale and financial responsibility is heavily upon the SSA national and regional governments [19]. In Tanzania, the government was forced to close any bioethanol production that may cause any threat to food and land security because that may result in unrest of farmers and environmental groups [5]. In order for bioethanol policies to be acceptable, the rural lifestyles need to be taken into consideration. Hence, sub-Saharan governments would prefer to financially support current policies rather than implement fuel development policies at the risk of extreme expenditure and social downfalls.

\section{Prospective for Bioethanol in Sub-Saharan Africa}

Recently, bioethanol technology is moving towards the use of second generation feedstocks for bioethanol. In SSA, bioethanol development is not at the level of other countries but it is foreseen that by the year 2050 the potential for bioenergy in SSA will increase from a current production of 347 exajoule to approximately 1548 exajoule [22].

To avoid food security issues, sugar cane and sweet sorghum are first-generation feedstocks that have the most potential. Since the starting production of bioethanol (see Section 3), sugar cane has been extensively exploited in SSA and can thus be reintroduced as an industrial crop. Sugar 
cane cultivation is dominant in Zimbabwe, South Africa, and Mauritius as climatic conditions are favorable for growth [18]. Total production in different countries, to date, ranges from 4,533 tonnes in Zimbabwe to 5,199 tonnes in Mauritius and 20,419 tonnes in South Africa [18]. If sugar cane juice is used for bioethanol, market sucrose and price may not be affected [18]. The use of sweet sorghum is also promising, as like sugar cane growth conditions for sweet sorghum are favorable and the sorghum plant is able to survive drought conditions that are common in SSA. It has been suggested that sorghum processing can take place in sugar cane plants, and thus additional costs for ethanol plant developments are avoided [14].

South African government has proposed that $20-50 \%$ of biofuel renewable energy will be implemented by 2013, using sugar cane and sugar beet as bioethanol feedstocks. Additionally, in South Africa agricultural and forestry residues can be utilized for bioethanol production. Agricultural and forestry residues are lignocellulosic biomass such as maize stover, sugar cane bagasse, wheat straw, saw mill residue, and paper mill sludge. The capacity of these types of biomass that is indigenous and available in South Africa for bioethanol exploitation was reviewed by Lynd et al. [23]. Agricultural residues account for $12.3 \mathrm{Mt} / \mathrm{a}$, and forestry residues account for $5.0 \mathrm{Mt} / \mathrm{a}$ [23]. In Zambia, the biofuel association of Zambia (BAZ) initiated biofuel introduction into existing energy policies and research into the use of sweet sorghum with sugar cane for bioethanol production [5, 14]. In 2009, the Mozambican government proposed a National Biofuels Policy and Strategy, "The Resolution" [24]. The policy aims to (i) allocate specific land for bioethanol crops, (ii) choose crops such as sugar cane and sweet sorghum specifically for bioethanol, (iii) blend bioethanol at $5-10 \%(\mathrm{v} / \mathrm{v})$ with petrol, (iv) promote bioethanol markets by exports and to generate foreign currency, and (v) tariff for biomass electricity where bioethanol processing will generate electricity as a byproduct $[18,25]$. Another major prospect in SSA is the growing association with the European Union (EU) $[7,26,27]$. In SSA, land that is underutilized is being acquired by the EU to grow bioethanol crops which will then be exported to the EU [5]. This strategy showed promising and resulted in a declaration being signed in September 2008 in Addis Ababa, and the "EU-Africa Energy Partnership" was formed [26]. The agreement benefits both parties, where the EU can reduce the use of fossil fuels by $20 \%$ by the year 2020 [26] and SSA will gain international investment [5]. This agreement can be improved by involving SSA in the bioethanol production process to achieve bioethanol sustainability, and certain percentage of the biofuel crops grown in SSA should be solely used in SSA.

\subsection{Enzymatic Hydrolysis of Bitter Sorghum for Bioethanol} Production. Various studies have reported on the use of bitter sorghum grains (bird-proof varieties) for bioethanol production. However, production utilizing a basic microbrewery plant for potential commercial production has not been reported [28]. Bitter sorghum is an ideal source of feedstock for bioethanol because (i) it is readily cultivated in Africa with approximately 20 million tonnes produced annually mainly used for African traditional beer, (ii) it is beneficial for agronomical purposes as high tannin levels provide resistance to preharvest sprouting and mold prior to harvest, and (iii) it has a high starch content and amylase activity [28]. If hydrolysis and fermentation of sorghum in a microbrewery plant can produce sugar substrates with a satisfactory ethanol yield, the implementation of large-scale commercial production will be of interest to bioindustries. In addition, microbial contaminants associated with sorghum processing were investigated. Contamination is an important aspect of the microbrewery plant because it is indicative of the productivity and hygienic operational processes and quality of a processing plant [29]. This research, undertaken at the University of the Witwatersrand (Wits), South Africa, was expected to provide information regarding the use of a microbrewery plant as a reliable means of sorghum hydrolysis and fermentation for large-scale bioethanol production as well as microbiological stability during production processes $[28,29]$. The aims of this study were to (i) determine the level of bioethanol produced from unmalted bitter sorghum grains from a combination of commercial exogenous enzymes and two types of yeast species and (ii) investigate microbiological quality at the postmashing and postfermentation stages in a microbrewery plant $[28,29]$.

In this study, a two-step exogenous enzyme process of Cerezyme Sorghum and Fungamyl 800L was used for the hydrolysis of sorghum grain starch $[28,29]$. When unmalted bitter sorghum grains were subjected to the following mashing regime: addition of Cerezyme Sorghum at $55^{\circ} \mathrm{C}$ for $30 \mathrm{~min}$, boiling at $95^{\circ} \mathrm{C}$ for $60 \mathrm{~min}$, and addition of Fungamyl $800 \mathrm{~L}$ at $58^{\circ} \mathrm{C}$ for $60 \mathrm{~min}$ glucose, fructose, and maltose were produced based on a quantitative analysis [28, 29]. The total sugar extracted ranged from 55.2 to $58.2 \mathrm{~g} / \mathrm{L}$ [28]. The hydrolysis of sorghum without the addition of exogenous enzymes resulted in $22.6 \mathrm{~g} / \mathrm{L}$ of sugar extracted [28]. The combined activity of Cerezyme Sorghum and Fungamyl $800 \mathrm{~L}$ is sufficient to break down the starch of bitter sorghum, in particular, the Red Swazi variety that produced simple fermentable sugars. In this investigation [28], the total sugar content was lower than a previous report in which $130 \mathrm{~g} / \mathrm{L}$ of sugar was obtained using bitter sorghum grains [30]. The investigation by du Preez et al. [30] involved hydrolysis of sorghum grain using the commercial enzymes Termamyl $120 \mathrm{~L}$ and AMG 200L. In another related study, sorghum was hydrolyzed using a commercial $\alpha$-amylase extracted from Bacillus subtilis, and $63.50 \mathrm{~g} / \mathrm{L}$ of sugar was extracted [31]. Hence, it can be deduced that different types of commercial enzymes produce different sugar concentrations [28]. Another possible reason for the lower sugar yield could be the presence of tannins. The Red Swazi variety of sorghum grain used in the investigation by Deenanath et al. [28] contained 98\% tannin content. Tannins, phenolic compounds, bind with enzymes and form irreversible complexes. This will cause a reduction in the activity of the enzymes and, in turn, reduce sugar yields. The effect of tannins on the enzymatic activity of Cerezyme Sorghum and Fungamyl 800L is still inconclusive because enzyme-binding assays have not been done to verify this reasoning [28]. 
Fermentation of the sorghum hydrolyzate was conducted using Saccharomyces (S.) cerevisiae and Issatchenkia (I.) orientalis, separately. The fermentation patterns of the yeast species are different. S. cerevisiae is capable of utilizing the sugars within 5 days, whereas I. orientalis, a slow fermenting yeast, utilizes the sugars within 12 days [28]. The maximum ethanol concentration was $7 \%(\mathrm{v} / \mathrm{v})[28]$. For the control (hydrolysis without exogenous enzymes), $3 \%(\mathrm{v} / \mathrm{v})$ was the maximum ethanol concentration [28]. It is evident that the yeasts can grow and ferment using the available sugars under the following fermentation conditions: temperature $=19^{\circ} \mathrm{C}$, $\mathrm{pH}=4.0$, pitching rate of approximately 100 million cells $/ \mathrm{mL}$ for S. cerevisiae and 1 million cells $/ \mathrm{mL}$ for $I$. orientalis [28]. In comparison to other studies, similar results were reported by Suresh et al. [31], showing that $5 \%(\mathrm{v} / \mathrm{v})$ of bioethanol is produced using sorghum with simultaneous saccharification and fermentation [31]. Mamma et al. [32] reported that 3.5$4.9 \%(\mathrm{v} / \mathrm{v})$ of bioethanol is produced, and du Preez et al. [30] reported $12 \%(\mathrm{v} / \mathrm{v})$ of bioethanol production is possible.

Furthermore, enumeration and identification of microbiological populations which are unique to the Wits Microbrewery Plant during sorghum processing was investigated [29]. Microbiological analysis was performed at the postmashing and postfermentation stages. At the postmashing stage, plate counts revealed $<30$ colonies [29]. No significant microbial contaminants were found to be associated at this production stage, which could be due to high mashing temperatures that are unfavorable for the growth of microorganisms (MOs) or the presence of tannins with antimicrobial activity [29]. At the postfermentation stage, numerous MOs were detected. Plate counts ranged from 5.00 to $8.00 \mathrm{Log} \mathrm{CFU} / \mathrm{mL}$ [29]. High plate counts suggested that MOs were able to survive and proliferate under the specified fermentation conditions [29]. For the fermentation propagated with $S$. cerevisiae, plate counts ranged from 6.00 to $8.00 \mathrm{Log} \mathrm{CFU} / \mathrm{mL}$ at day 5. For the fermentation propagated with $I$. orientalis, plate counts were in the range of 5.00-7.00 Log CFU/mL at day 12 [29]. The difference in plate counts between two fermentations could be due to the decreased nutrients and oxygen availability as the duration of fermentation increased from 5 to 12 days. Low nutrients and oxygen availability favor decline in microbial numbers [29]. The microbial populations were isolated and identified based on polymerase chain reaction (PCR) amplification of the 16S and internal transcribed spacer (ITS) regions [29]. Following PCR, the isolates, from the fermentations using both S. cerevisiae and I. orientalis, were sequenced [29]. Sequencing results identified the isolates as the following species: Lactococcus lactis, Lactococcus garvieae, Lactobacillus casei, Enterococcus (E.) faecalis, S. cerevisiae strains NCL 117 and T8, S. paradoxus, S. pastorianus, S. kudriavzevii, and Candida inconspicua [29]. The occurrence of LAB species coincides with LAB previously identified from traditional sorghum beer [33]. The presence of E. faecalis was unusual and is possibly a contaminant of the water, rather than a product of the fermentation process [29]. The yeast species identified correspond to the sensu stricto strains of species, commonly associated with African sorghum beer [34]. The microbial community present at the postfermentation stage is multifactorial, as contamination could be contributed by (i) use of unsterilized grain, (ii) low $\mathrm{pH}$ and temperature conditions during fermentation, (iii) sources of sugar substrates, and (iv) contaminated equipment such as pipes and vessels [29].

In a summary, two-step enzymatic hydrolysis increased bioethanol levels from $3 \%$ to $7 \%(\mathrm{v} / \mathrm{v})$ using unmalted sorghum grains [28]. Fermentable sugars such as glucose, maltose, and fructose can be produced from the commercial enzyme combination of Cerezyme Sorghum and Fungamyl 800L [28]. The yeast species, S. cerevisiae and I. orientalis are capable of fermenting the extracted sugars. The evidence supports the idea that bioethanol production is possible from unmalted sorghum grains and the microbrewery plant can be used as a production plant [28]. Microbial identification showed lactic acid bacteria, Saccharomyces and non- Saccharomyces wild yeasts are inhabitants of the Wits Microbrewery plant during sorghum fermentation [29]. It is possible that these contaminants affect the bioethanol yield as there is substrate antagonism between contaminants and the pitching yeast during fermentation [29]. Further recommendations to improve the bioethanol yield include pretreating the grains to remove tannins, nutrient supplementation to improve fermentation rate, increasing hydrolysis time and enzyme concentration to extract more sugars, installation of an agitator in the fermentor of the microbrewery plant to maintain yeast in suspension to acquire nutrients for proliferation and to decrease the lag phase, and implementation of cleaning in place (CIP) strategies to control microbial contamination $[28,29]$.

4.2. Production of Bioethanol from Cashew Apple Juice for the Use in Internal Combustion Engine. Agricultural feedstocks including wheat, barley, sorghum, rice, corn, and sugar cane, and agricultural residues such as barley straw, barley husks, corn stover, sugar cane bagasse, and switchgrass can all be used for the production of bioethanol $[3,4,8,9$, $35,36]$. However, the use of cereal grains as a mainstream feedstock for bioethanol production is limited because they are important food source for human consumption (see Section 3). Second-generation feedstocks can also be utilized for bioethanol production but these require intensive pretreatment technologies $[6,13,16,17]$. An attractive and unconventional feedstock for bioethanol is the agricultural waste product such as cashew apples [37-40]. Cashew apple is a pseudofruit or peduncle from which the cashew nut grows. This apple is a small, hard, pear-shaped, nonclimacteric, green fruit and turns red, yellow or orange when it is ripen [40-42]. SSA, Mozambique, and Tanzania are the largest cashew apple-producing countries, where the cashew apples are discarded after cashew nuts are harvested [37, 39, 43]. Cashew apples are regarded as waste because they are usually decomposed in the soil without producing any value of relevant by products $[24,38,39,44]$. Recently, a study was initiated at Wits, South Africa to use cashew apples for bioethanol production. Cashew apple offers several advantages over other sources of feedstocks for biofuel: (i) cashew apple juice (CAJ) extracted from the apple contains 
abundant reducing sugars $(50-200 \mathrm{~g} / \mathrm{L}$ ); (ii) CAJ is rich in organic acid, minerals and amino acids necessary for yeast growth; (iii) it is inexpensive source of sugars; (iv) pretreatment method is simple and hydrolysis is not required; (v) it avoids food security issues, and readily available in large quantities as cashew apples are neglected in their cultivation areas after harvesting of the nut $[37,39,40,43]$.

Another aspect of this investigation is to optimize ratio of bioethanol blended with petrol. Chemical fingerprinting is an analytical method used to determine compounds that are unique to chemical samples [45]. Various studies to date have reported on the use of chemical fingerprinting to characterize polynuclear aromatic hydrocarbons (PAHs) associated with (i) environmental pollution by oil spills, (ii) contamination of soils by tar and/or petrol, and (iii) automotive evaporated and unevaporated petrol [25, 4549]. For this study, chemical fingerprinting can identify the signature of bioethanol-petrol blends. A petrol generator will be fuelled with bioethanol-petrol blends to interpret performance in an engine, as the blends act as "spark ignition engine fuel" [50].

In this study, cashew apple juice (CAJ) will be extracted, and characterized for tannins, sugars, minerals and vitamin C content [51]. For pretreatment, gelatin powder will be added to the CAJ followed by refrigeration for approximately $4 \mathrm{hrs}$ and centrifugation. A pure yeast strain S. cerevisiae NRRL Y2084, previously isolated from dry brewer's yeast and maintained at $-70^{\circ} \mathrm{C}$ in $50 \%$ glycerol $[28,29]$, will be used for fermentation. The yeast strain will be activated by extracting the glycerol and resuspending the pellet in yeast peptone dextrose (YPD) liquid medium. Following activation, cells will be cultivated in YPD broth as previously described $[28,29]$. Bioethanol will be processed from CAJ in a BIOSTAT BPlus fermentor (Figure 4, Table 2) housed at Wits, South Africa. The fermentor is a double-walled, $2 \mathrm{~L}$ $\mathrm{MO}-\mathrm{O}_{2}$ lab scale plant that is automated and controlled. It is comprised of stainless steel housing, digital controller, operating interface, gassing system, controlled motor, thermostat system, peristaltic pumps, and amplifiers. As an integrated system it is controlled by the digital controller which is designed to handle input and output signals of the process using a graphical and touch screen interface. This allows for the controlling of amplifiers such as temperature, $\mathrm{pH}$, oxygen, foam level, agitation, gas mixing, and air flow. Values for the amplifiers are configured and controlled throughout the process via the digital control system. For fermentation, pretreated CAJ will be inoculated with active yeast cells and fermented for 2-5 days. Batch fermentation will be performed in the $2 \mathrm{~L}$ vessel, with a $1.5 \mathrm{~L}$ working volume. Possible fermentation conditions will be set and controlled as follows:

(1) temperature control at $30^{\circ} \mathrm{C}$,

(2) sparging with oxygen at the point of yeast addition,

(3) stirring speed at $150 \mathrm{rpm}$,

(4) $\mathrm{pH}$ at $4.5 \pm 0.1$ with intermittent supply of $1 \mathrm{M} \mathrm{HCL} /$ $\mathrm{NaOH}$,

(5) dosing of antifoam level (level sensor),

(6) dosing of $\mathrm{NH}_{4} \mathrm{SO}_{4}$ every $24 \mathrm{hrs}$.
TABLE 2: Description of the main P\&ID components.

\begin{tabular}{ll}
\hline Tag-No & Description \\
\hline FI-464 & Rotameter: 0.42-4.2 lpm-QFlow 8O \\
FC-3056 & Mass Flow Control 0.06-3 lpm, Air \\
BT-650-850 & 250 mL storage bottles \\
P-651-951 & On/off controls \\
QE-3022 & pH sensor \\
LE-3006 & Level sensor \\
LE-3008 & Antifoam sensor \\
PT-162 & Four way hose fitting \\
M-120 & Stirrer system 200 W \\
AG-123 & 6-blade disk impeller \\
SPA-141 & Ring sparger \\
MS-105 & 20 mL manual sampler \\
QE-3023 & pO \& pH sensor \\
TE-3021 & Temperature sensor Pt 100 \\
H-300 & Thermostat \\
\hline
\end{tabular}

During fermentation, sample will be extracted via the manual sampler (Figure 4; Table 2) for the analysis of ethanol progression and sugar consumption at $24 \mathrm{hr}$ intervals. Furthermore, offline analysis and data acquisition of the fermentation process data will be carried out by the BioPAT MFCS/ SCADA software programme.

A mass balance model to evaluate the theoretical conversion of the experimental process is represented in Figure 5.

Theoretical process data is as follows: $85 \%$ recovery of CAJ from 10 tonnes/ha of cashew apples; $1 \%(\mathrm{w} / \mathrm{v})$ of gelatin; $46.34 \mathrm{~g} / \mathrm{L}$ of glucose and $45.25 \mathrm{~g} / \mathrm{L}$ of fructose; $10 \mathrm{~g} / \mathrm{L}$ yeast, $2.5 \mathrm{~g} / \mathrm{L} \mathrm{N} \mathrm{NH}_{4} \mathrm{SO}_{4}, 44 \mathrm{~g} / \mathrm{L}$ of ethanol produced, $3.77 \mathrm{~g} / \mathrm{L}$ of residual sugar; 10-14 ppm of oxygen; $94 \%$ (w/w) recovery of ethanol by distillation; 1069 is the specific gravity of cashew apple juice [12, 25].

Prior to characterization, samples will be filtered to remove yeast particles and distilled to obtain pure alcohol. Distilled bioethanol at a $5 \%(\mathrm{v} / \mathrm{v})$ concentration will be blended with $95 \%(\mathrm{v} / \mathrm{v})$ petroleum (SASOL) and the properties characterized by Proton $\left({ }^{1} \mathrm{H}\right)$-NMR analysis [52]. After characterization, the fuel blends will be run in a $2.6 \mathrm{kVa}$ petrol silent generator to learn how the performance in an engine will be influenced.

This study will contribute knowledge to Bioindustries in SSA and the world regarding the use of cashew apples for bioethanol production. Based on chemical characterization of bioethanol-petrol blends and the application of the blends in a generator, the research will demonstrate that the endproduct of cashew apples can be used as an alternative fuel.

\section{Summary}

Bioethanol production is a strategy that will aid in reducing carbon emissions, decreasing the use of fossil fuels and stress of the decline of crude oil availability. In SSA, bioethanol production is stagnant. This paper focused on the history, challenges, and prospects of bioethanol production in SSA. 


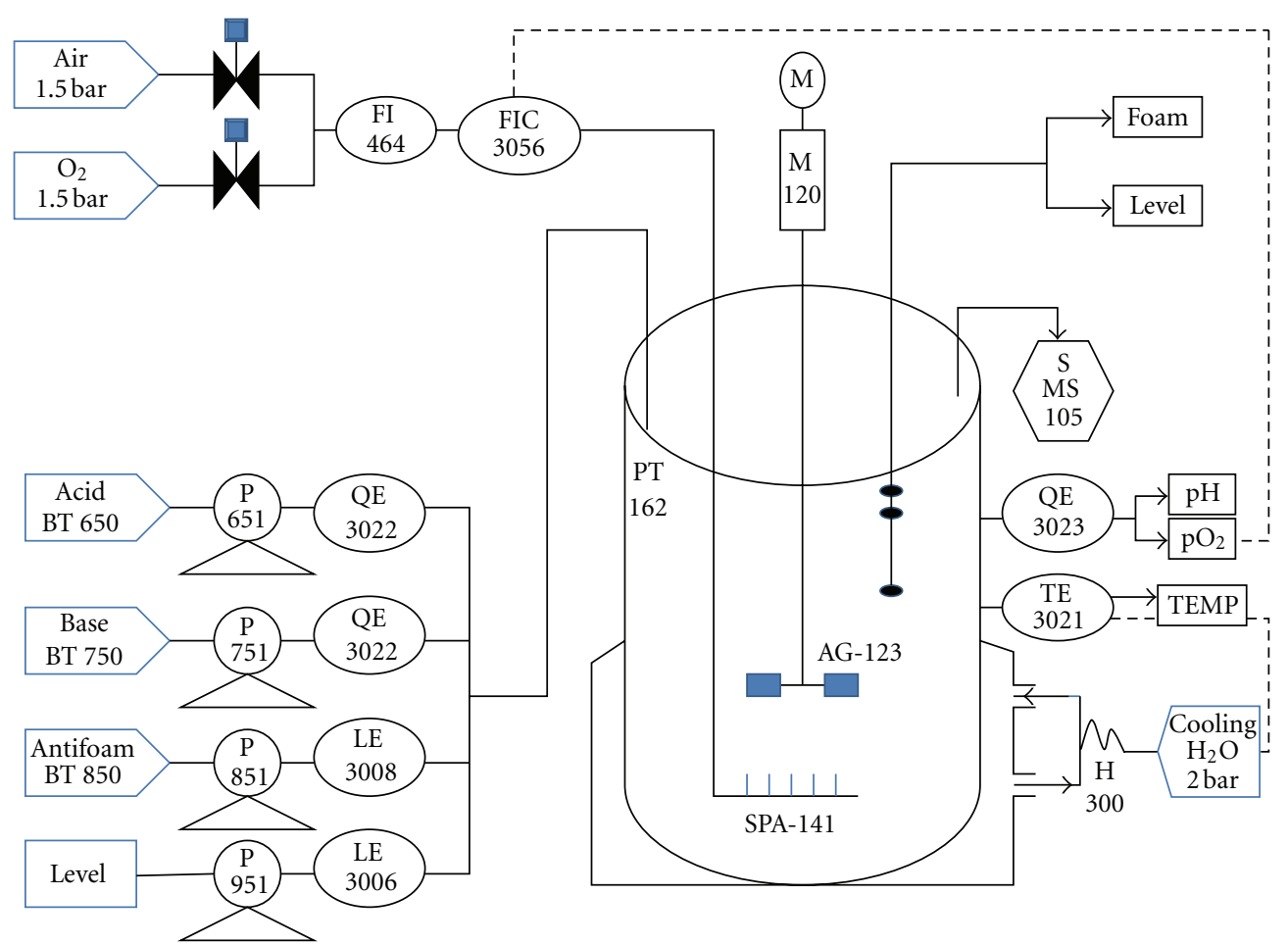

Figure 4: P\&ID diagram of the BIOSTAT BPlus fermentor.

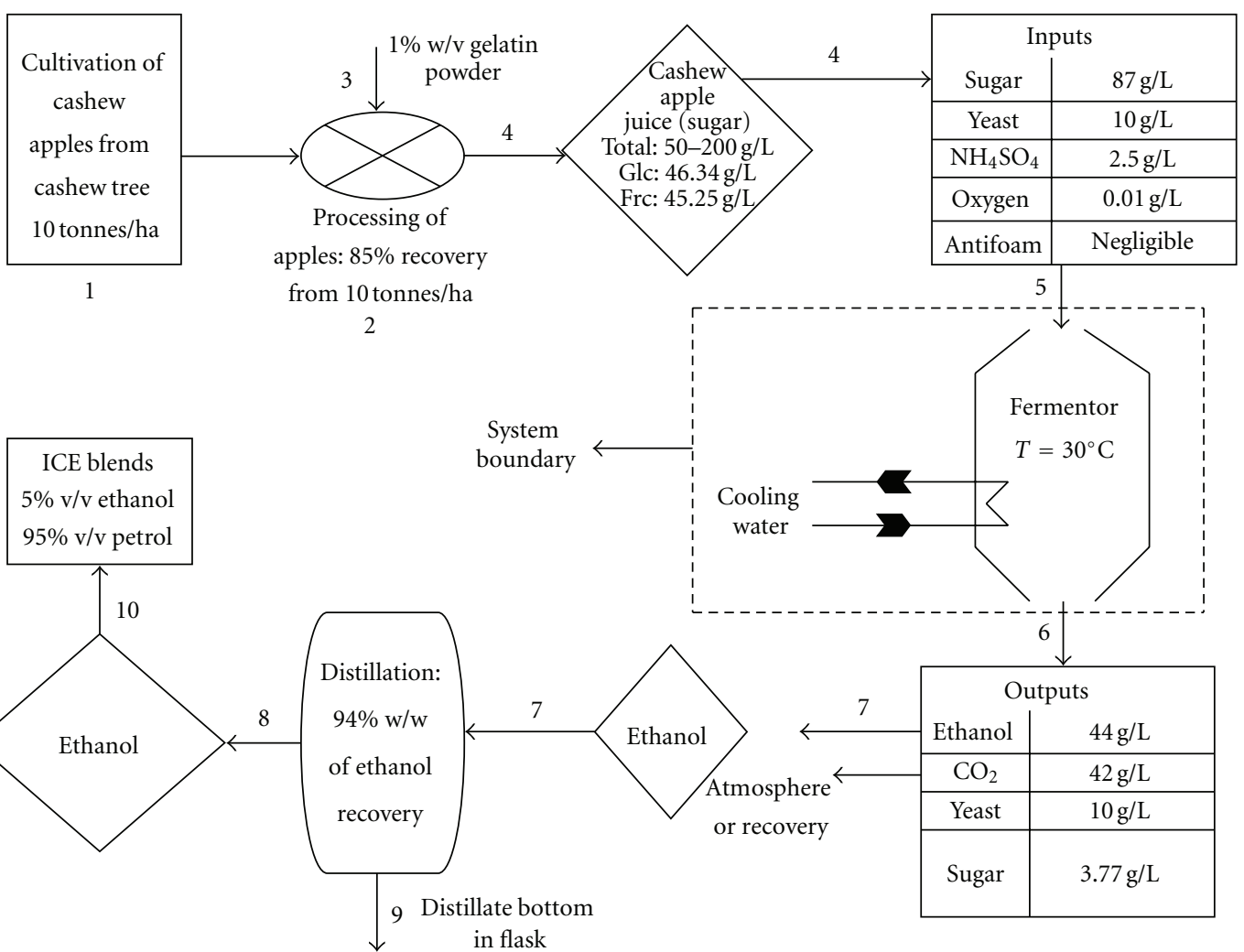

FIGURE 5: Mass flow diagram of the experimental process. 
The production of bioethanol in SSA began during the 1980s. The Zimbabwean Triangle Ethanol Plant, Dwangwa Estate Plant, and Muhoroni Plant were developed for bioethanol production in Zimbabwe, Malawi, and Kenya, respectively. These plants used sugar cane and sugar cane molasses as the main feedstocks. With the exception of the Dwangwa Plant, the Zimbabwean Triangle Ethanol and Muhoroni plants were shut down due to lack of government support. Other challenges faced in SSA, for example, availability of grain crops, land availability and development, and government policies have been detrimental to the long success of bioethanol production. In SSA, the demand for food for the human population from grain crops is greater than the need for bioethanol. Another issue is the land smallholder farmers that own the land and provide food through farming will be disadvantaged if their land is developed for fuel crops. With regards to government policies, there are no sustainable policies to support bioethanol development, as poverty and the dependence on agriculture for food are of greater concern. It is clear from these challenges that the advantages of bioethanol development in SSA are overshadowed. However, there are beneficial prospects that were considered. These prospects include the use of feedstocks that are abundantly available in SSA and will not affect the food market. Examples of these are sweet sorghum, stalks of the sorghum plant, sugar cane, and sugar beets. Additional feedstocks are agricultural and forestry residues such as maize stover or sugar cane bagasse. Government policies implemented thus far involve (i) research into the use of sweet sorghum by BAZ, (ii) the resolution policy by the Mozambican government, and (iii) the international partnership between the EU and Africa. Furthermore, this review dealt with research studies undertaken at Wits, South Africa to provide insight on the prospects of bioethanol production from unconventional feedstocks such as bitter sorghum and CAJ. It has been shown that bioethanol could be successfully produced from un-malted bitter sorghum grains with the use of a microbrewery processing plant. However, further investigation to improve the bioethanol yield is necessary for commercialization. As a second option, the use of CAJ for bioethanol production was motivation for research because cashew apples are an agroindustrial waste product that is not utilized commercially and largely available in Mozambique and Tanzania. Bioethanol will be produced from CAJ in a BIOSTAT BPlus Fermentor under controlled conditions. During fermentation, ethanol progression and sugar consumption will be monitored. After fermentation, the ethanol produced will be distilled and blended at a $5 \%(\mathrm{v} / \mathrm{v})$ concentration with $95 \%(\mathrm{v} / \mathrm{v})$ of petroleum and characterized. The ethanol-petrol blend will then be run in a petrol silent generator to detect the performance in an engine. This research will contribute knowledge to Bioindustries in SSA regarding the use of cashew apples as an alternative fuel feedstock. Recognizing the efforts towards bioethanol development is imperative for further progress in this field. It is hoped that the SSA government will continue to formulate policies that are strong and comprehensive to promote biofuels. Additionally, policies for the involvement of academic research sectors should be implemented, as a way of testing production plants to perfect the technology for commercialization.

\section{Acknowledgments}

The authors kindly acknowledge the DAAD-NRF Joint Scholarship Programme and IBD Africa Section-Food Bev SETA (Research Grant), for financial support; Falcon Engineering-South Africa (Pty) Ltd., for supplying the Microbrewery Plant; LABOTEC-Midrand, South Africa, for supplying the BIOSTAT BPlus Fermentor; Sampie J. van Vuuren (Product Manager-Labotec SA), for technical support and training of the BIOSTAT BPlus Fermentor.

\section{References}

[1] B. P. Chapagain, Y. Yehoshua, and Z. Wiesman, "Desert date (Balanites aegyptiaca) as an arid lands sustainable bioresource for biodiesel," Bioresource Technology, vol. 100, no. 3, pp. 12211226, 2009.

[2] P. Girard and A. Fallot, "Review of existing and emerging technologies for the production of biofuels in developing countries," Energy for Sustainable Development, vol. 10, no. 2, pp. 92-108, 2006.

[3] M. Balat and H. Balat, "Recent trends in global production and utilization of bio-ethanol fuel," Applied Energy, vol. 86, no. 11, pp. 2273-2282, 2009.

[4] B. Amigun, R. Sigamoney, and H. von Blottnitz, "Commercialisation of biofuel industry in Africa: a review," Renewable and Sustainable Energy Reviews, vol. 12, no. 3, pp. 690-711, 2008.

[5] B. Amigun, J. K. Musango, and W. Stafford, "Biofuels and sustainability in Africa," Renewable and Sustainable Energy Reviews, vol. 15, no. 2, pp. 1360-1372, 2011.

[6] M. Balat, H. Balat, and C. Öz, "Progress in bioethanol processing," Progress in Energy and Combustion Science, vol. 34, no. 5, pp. 551-573, 2008.

[7] A. Demirbas, "Biofuels sources, biofuel policy, biofuel economy and global biofuel projections," Energy Conversion and Management, vol. 49, no. 8, pp. 2106-2116, 2008.

[8] S. Kim and B. E. Dale, "Global potential bioethanol production from wasted crops and crop residues," Biomass and Bioenergy, vol. 26, no. 4, pp. 361-375, 2004.

[9] M. Linde, M. Galbe, and G. Zacchi, "Bioethanol production from non-starch carbohydrate residues in process streams from a dry-mill ethanol plant," Bioresource Technology, vol. 99, no. 14, pp. 6505-6511, 2008.

[10] G. M. Walker, "Fuel alcohol: current production and future challenges," Journal of the Institute of Brewing, vol. 117, no. 1, pp. 3-22, 2011.

[11] L. Di Lucia, "External governance and the EU policy for sustainable biofuels, the case of Mozambique," Energy Policy, vol. 38, no. 11, pp. 7395-7403, 2010.

[12] K. R. Jegannathan, E. S. Chan, and P. Ravindra, "Harnessing biofuels: a global Renaissance in energy production?" Renewable and Sustainable Energy Reviews, vol. 13, no. 8, pp. 21632168, 2009.

[13] O. J. Sánchez and C. A. Cardona, "Trends in biotechnological production of fuel ethanol from different feedstocks," Bioresource Technology, vol. 99, no. 13, pp. 5270-5295, 2008.

[14] E. Chakauya, G. Beyene, and R. K. Chikwamba, "Food production needs fuel too: perspectives on the impact of biofuels 
in southern Africa," South African Journal of Science, vol. 105, no. 5-6, pp. 174-181, 2009.

[15] C. S. Goh and K. T. Lee, "A visionary and conceptual macroalgae-based third-generation bioethanol (TGB) biorefinery in Sabah, Malaysia as an underlay for renewable and sustainable development," Renewable and Sustainable Energy Reviews, vol. 14, no. 2, pp. 842-848, 2010.

[16] Y. Sun and J. Cheng, "Hydrolysis of lignocellulosic materials for ethanol production: a review," Bioresource Technology, vol. 83, no. 1, pp. 1-11, 2002.

[17] A. K. Chandel, C. Es, R. Rudravaram, M. L. Narasu, L. V. Rao, and P. Ravindra, "Economics and environmental impact of bioethanol production technologies: an appraisal," Biotechnology and Molecular Biology Review, vol. 2, no. 1, pp. 014-032, 2007.

[18] F. X. Johnson and E. Matsika, "Bio-energy trade and regional development: the case of bio-ethanol in southern Africa," Energy for Sustainable Development, vol. 10, no. 1, pp. 42-53, 2006.

[19] C. B. L. Jumbe, F. B. M. Msiska, and M. Madjera, "Biofuels development in Sub-Saharan Africa: are the policies conducive?" Energy Policy, vol. 37, no. 11, pp. 4980-4986, 2009.

[20] S. Karekezi, "Renewables in Africa-Meeting the energy needs of the poor," Energy Policy, vol. 30, no. 11-12, pp. 1059-1069, 2002.

[21] R. B. Mangoyana, "Bioenergy for sustainable development: an African context," Physics and Chemistry of the Earth, vol. 34, no. 1-2, pp. 59-64, 2009.

[22] E. M. W. Smeets, A. P. C. Faaij, I. M. Lewandowski, and W. C. Turkenburg, "A bottom-up assessment and review of global bio-energy potentials to 2050," Progress in Energy and Combustion Science, vol. 33, no. 1, pp. 56-106, 2007.

[23] L. R. Lynd, H. Von Blottnltz, B. Tait et al., "Converting plant biomass to fuels and commodity chemicals in South Africa: a third chapter?" South African Journal of Science, vol. 99, no. 11-12, pp. 499-507, 2003.

[24] R. P. Santos, A. A. X. Santiago, C. A. A. Gadelha et al., "Production and characterization of the cashew (Anacardium occidentale L.) peduncle bagasse ashes," Journal of Food Engineering, vol. 79, no. 4, pp. 1432-1437, 2007.

[25] P. M. L. Sandercock and E. Du Pasquier, "Chemical fingerprinting of gasoline: 2. Comparison of unevaporated and evaporated automotive gasoline samples," Forensic Science International, vol. 140, no. 1, pp. 43-59, 2004.

[26] M. B. Charles, R. Ryan, R. Oloruntoba, T. V. D. Heidt, and N. Ryan, "The EU-Africa Energy Partnership: towards a mutually beneficial renewable transport energy alliance?" Energy Policy, vol. 37, no. 12, pp. 5546-5556, 2009.

[27] M. Schut, M. Slingerland, and A. Locke, "Biofuel developments in Mozambique. Update and analysis of policy, potential and reality," Energy Policy, vol. 38, no. 9, pp. 5151-5165, 2010.

[28] E. D. Deenanath, S. E. Iyuke, D. Lindsay et al., "Enzymatic Hydrolysis of Bitter Sorghum for Bioethanol Production," Master Brewers Association of the Americas-MBAA TQ, 2010.

[29] E. D. Deenanath, S. E. Iyuke, and D. Lindsay, "Identification of Microbial Populations associated with Sorghum Fermentation," Master Brewers Association of the Americas-MBAA TQ, 2010.

[30] J. C. du Preez, F. de Jong, P. J. Botes, and P. M. Lategan, "Fermentation alcohol from grain sorghum starch," Biomass, vol. 8, no. 2, pp. 101-117, 1985.

[31] K. Suresh, N. Kiransree, and L. V. Rao, "Production of ethanol by raw starch hydrolysis and fermentation of damaged grains of wheat and sorghum," Bioprocess Engineering, vol. 21, no. 2, pp. 165-168, 1999.

[32] D. Mamma, D. Koullas, G. Fountoukidis, D. Kekos, B. J. Macris, and E. Koukios, "Bioethanol from sweet sorghum: simultaneous saccharification and fermentation of carbohydrates by a mixed microbial culture," Process Biochemistry, vol. 31, no. 4, pp. 377-381, 1996.

[33] T. L. Pattison, I. Geornaras, and A. Von Holy, "Microbial populations associated with commercially produced South African sorghum beer as determined by conventional and Petrifilm plating," International Journal of Food Microbiology, vol. 43, no. 1-2, pp. 115-122, 1998.

[34] E. S. Naumova, I. V. Korshunova, L. Jespersen, and G. I. Naumov, "Molecular genetic identification of Saccharomyces sensu stricto strains from African sorghum beer," FEMS Yeast Research, vol. 3, no. 2, pp. 177-184, 2003.

[35] M. Linde, M. Galbe, and G. Zacchi, "Simultaneous saccharification and fermentation of steam-pretreated barley straw at low enzyme loadings and low yeast concentration," Enzyme and Microbial Technology, vol. 40, no. 5, pp. 1100-1107, 2007.

[36] G. Najafi, B. Ghobadian, T. Tavakoli, and T. Yusaf, "Potential of bioethanol production from agricultural wastes in Iran," Renewable and Sustainable Energy Reviews, vol. 13, no. 6-7, pp. 1418-1427, 2009.

[37] T. L. Honorato, M. C. Rabelo, L. R. B. Gonçalves, G. A. S. Pinto, and S. Rodrigues, "Fermentation of cashew apple juice to produce high added value products," World Journal of Microbiology and Biotechnology, vol. 23, no. 10, pp. 1409-1415, 2007.

[38] T. L. Honorato and S. Rodrigues, "Dextransucrase stability in cashew apple juice," Food and Bioprocess Technology, vol. 3, no. 1, pp. 105-110, 2010.

[39] D. A. Luz, A. K. O. Rodrigues, F. R. C. Silva et al., "Adsorptive separation of fructose and glucose from an agroindustrial waste of cashew industry," Bioresource Technology, vol. 99, no. 7, pp. 2455-2465, 2008.

[40] M. V. P. Rocha, A. H. S. Oliveira, M. C. M. Souza, and L. R. B. Gonçalves, "Natural cashew apple juice as fermentation medium for biosurfactant production by Acinetobacter calcoaceticus," World Journal of Microbiology and Biotechnology, vol. 22, no. 12, pp. 1295-1299, 2006.

[41] A. J. MacLeod and N. G. de Troconis, "Volatile flavour components of cashew 'apple' (Anacardium occidentale)," Phytochemistry, vol. 21, no. 10, pp. 2527-2530, 1982.

[42] A. M. Pancheo, D. R. Gondim, and L. R. B. Goncalves, "Ethanol production by fermentation using immobilized yeast cells of Saccharomyces cerevisiae," Applied Biochemistry and Biotechnology, vol. 161, pp. 209-217, 2010.

[43] M. S. Silveira, C. P. M. L. Fontes, A. A. Guilherme, F. A. N. Fernandes, and S. Rodrigues, "Cashew Apple Juice as Substrate for Lactic Acid Production," Food Bioprocess Technology, 2010.

[44] A. D. T. Pinheiro, M. V. P. Rocha, G. R. MacEdo, and L. R. B. Gonçalves, "Evaluation of cashew apple juice for the production of fuel ethanol," Applied Biochemistry and Biotechnology, vol. 148, no. 1-3, pp. 227-234, 2008.

[45] P. D. Boehm, G. S. Douglas, W. A. Burns, P. J. Mankiewicz, D. S. Page, and A. E. Bence, "Application of petroleum hydrocarbon chemical fingerprinting and allocation techniques after the Exxon Valdez oil spill," Marine Pollution Bulletin, vol. 34, no. 8, pp. 599-613, 1997.

[46] R. Alzaga, P. Montuori, L. Ortiz, J. M. Bayona, and J. Albaigés, "Fast solid-phase extraction-gas chromatography-mass spectrometry procedure for oil fingerprinting: application to the 
Prestige oil spill," Journal of Chromatography A, vol. 1025, no. 1, pp. 133-138, 2004.

[47] A. O. Barakat, A. R. Mostafa, Y. Qian, and M. C. Kennicutt, "Application of petroleum hydrocarbon chemical fingerprinting in oil spill investigations-Gulf of Suez, Egypt," Spill Science and Technology Bulletin, vol. 7, no. 5-6, pp. 229-239, 2002.

[48] W. J. Havenga and E. R. Rohwer, "Chemical characterization and screening of hydrocarbon pollution in industrial soils by headspace solid-phase microextraction," Journal of Chromatography A, vol. 848, no. 1-2, pp. 279-295, 1999.

[49] P. M. L. Sandercock and E. Du Pasquier, "Chemical fingerprinting of unevaporated automotive gasoline samples," Forensic Science International, vol. 134, no. 1, pp. 1-10, 2003.

[50] C. D. Rakopoulos, K. A. Antonopoulos, D. C. Rakopoulos, D. T. Hountalas, and E. G. Giakoumis, "Comparative performance and emissions study of a direct injection Diesel engine using blends of Diesel fuel with vegetable oils or bio-diesels of various origins," Energy Conversion and Management, vol. 47, no. 18-19, pp. 3272-3287, 2006.

[51] S. T. Lowor and C. K. Agyeute-Badu, "Mineral and proximate composition of cashew apple (Anarcadium occidentale L.) juice from northern savannah, forest and coastal savannah regions in Ghana," American Journal of Food Technology, vol. 4, no. 4, pp. 154-161, 2009.

[52] H. P. J. M. Noteborn, A. Lommen, R. C. Van Der Jagt, and J. M. Weseman, "Chemical fingerprinting for the evaluation of unintended secondary metabolic changes in transgenic food crops," Journal of Biotechnology, vol. 77, no. 1, pp. 103-114, 2000.

[53] E. W. de Menezes, R. Cataluña, D. Samios, and R. D. Silva, "Addition of an azeotropic ETBE/ethanol mixture in eurosuper-type gasolines," Fuel, vol. 85, no. 17-18, pp. 2567-2577, 2006.

[54] D. Turner, H. Xu, R. F. Cracknell, V. Natarajan, and X. Chen, "Combustion performance of bio-ethanol at various blend ratios in a gasoline direct injection engine," Fuel, vol. 90, pp. 1999-2006, 2011. 

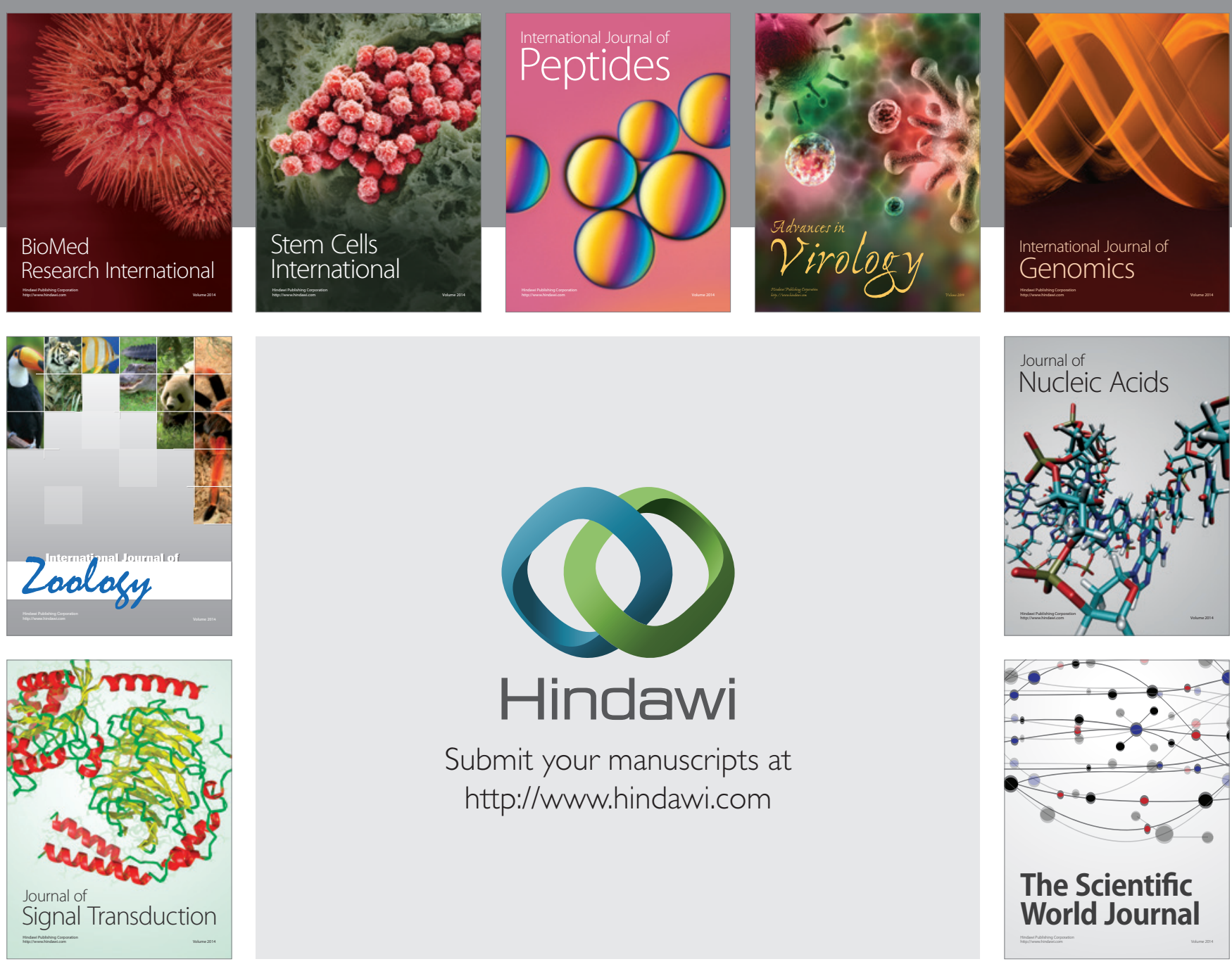

Submit your manuscripts at

http://www.hindawi.com
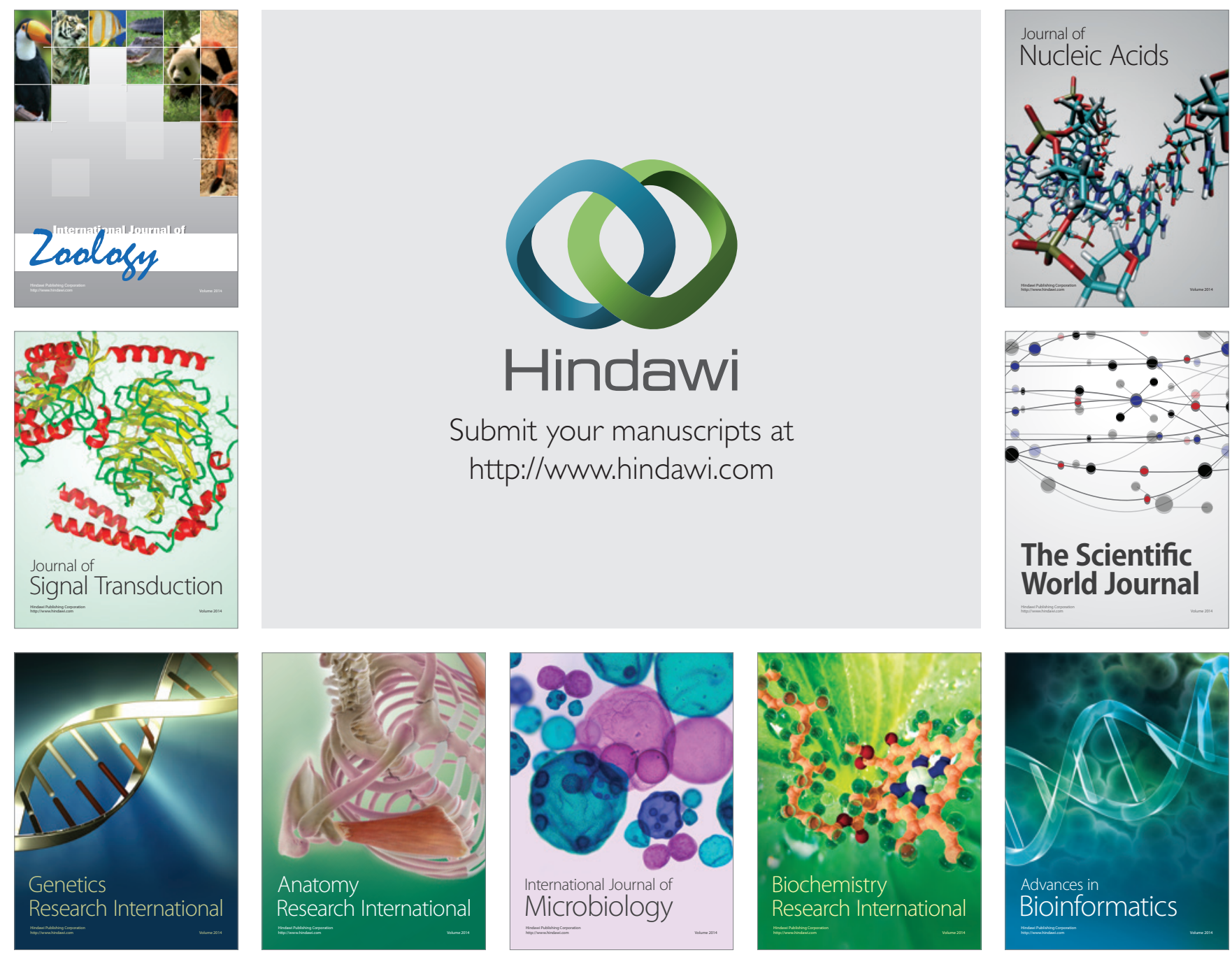

The Scientific World Journal
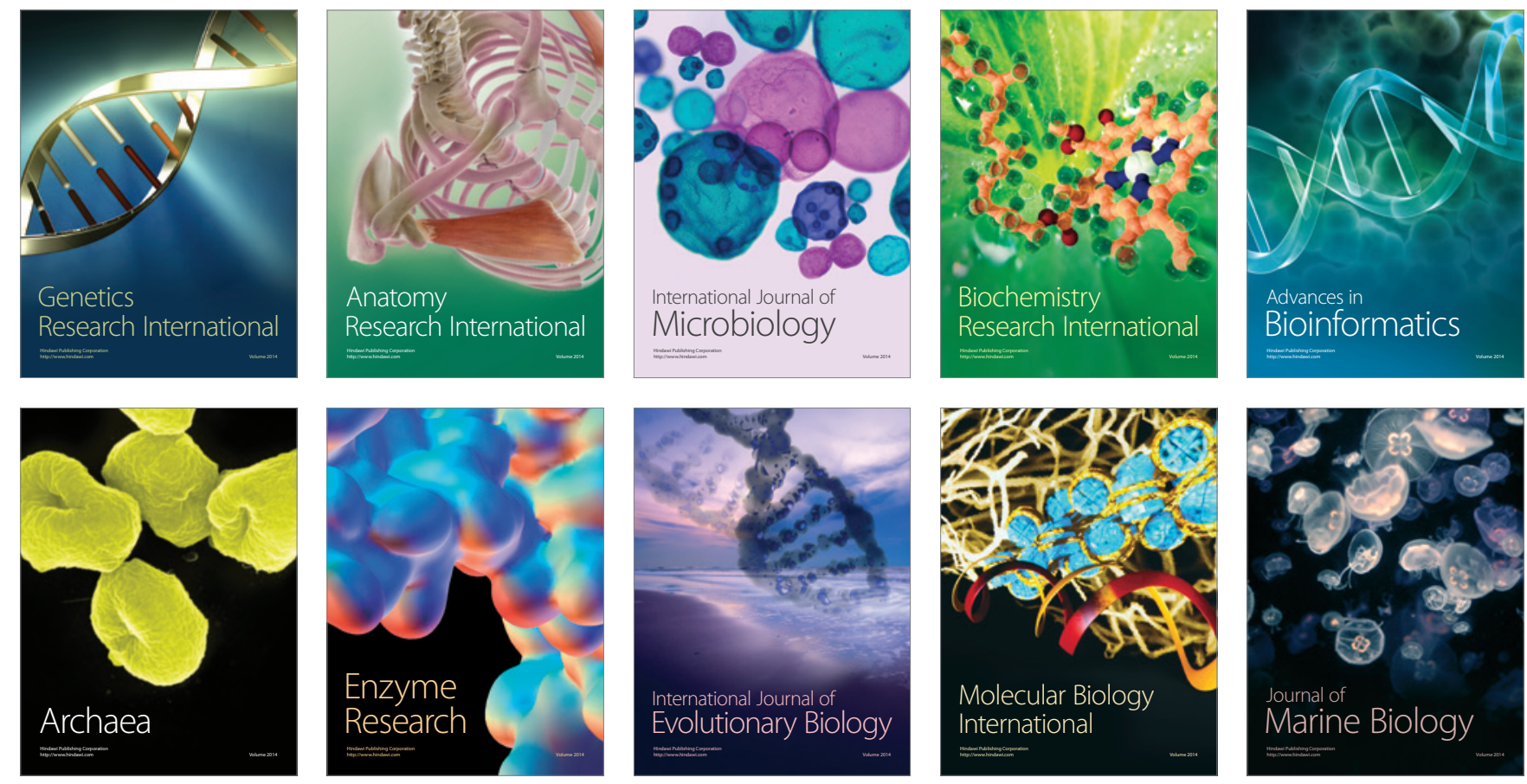